\title{
Production of indole acetic acid by Kocuria rosea VB1 and Arthrobacter luteolus VB2 under the influence of L-tryptophan and maize root exudates
}

\author{
ARUN KaRNWAL \\ School of Bioengineering and Biosciences, Lovely Professional University, Punjab, India
}

\begin{abstract}
Phytohormones play a very important role in enhancing plant growth by direct or indirect mechanisms involving plant-microbe interactions. Indole acetic acid (IAA) is one of the key phytohormones that directly enhance plant development. Kocuria rosea VB1 (GenBank ID: KY608093.1) and Arthrobacter luteolus VB2 (GenBank ID: KY608094.1) from polluted industrial water samples were characterized through a biochemical assay, 16S rDNA sequencing, and for promoting plant growth abilities. IAA production by VB1 and VB2 was tested in pure culture conditions supplemented with various L-tryptophan (Trp) concentrations $\left(0,50,100,200\right.$, and $\left.500 \mu \mathrm{g} \cdot \mathrm{ml}^{-1}\right)$. A significant difference in indole production by VB2 and VB1 inoculant at various L-Trp concentrations has been observed. VB1 has been reported to produce increased amounts of indole from $0.33 \mu \mathrm{g} \cdot \mathrm{ml}^{-1}$ to $18.16 \mu \mathrm{g} \cdot \mathrm{ml}^{-1}$, while the increase in indole production was from $0.63 \mu \mathrm{g} \cdot \mathrm{ml}^{-1}$ to $9.22 \mu \mathrm{g} \cdot \mathrm{ml}^{-1}$ for VB2 for various L-Trp concentrations. The VB1 strain produced $85.07 \mathrm{ng} \cdot \mathrm{ml}^{-1}$ and $123.7 \mathrm{ng} \cdot \mathrm{ml}^{-1} \mathrm{IAA}$, whereas the VB2 strain produced $70.3 \mathrm{ng} \cdot \mathrm{ml}^{-1}$ and $78.4 \mathrm{ng} \cdot \mathrm{ml}^{-1} \mathrm{IAA}$, respectively at 200 and $500 \mu \mathrm{g} \cdot \mathrm{ml}^{-1}$ Trp concentrations. The growth pouch experiments with maize root exudates also showed a positive effect for both bacterial inoculants tested on IAA biosynthesis in comparison to non-inoculated seeds. Inoculation of maize seeds with VB2 and VB1 bacteria gave a significantly higher level of IAA production in comparison to non-inoculated seeds. Current study outcomes show the beneficial aspects of plant growth regulators produced by free-living bacteria which could play a significant role in plant growth promotion.
\end{abstract}

Key words: $16 \mathrm{~s}$ rDNA sequencing, phytohormones, plant growth promotion, rhizosphere, waste water

\section{Introduction}

Plant growth hormones are natural organic chemicals which are biosynthesized at particular life stages in the plants and regulate their growth (Asari et al., 2016). They have a detectable physiological impact upon plant development even at extremely low concentrations. Microbial biosynthesized plant growth regulators are often an effective mechanism to improve plant growth and result in diversified benefits from the reduction of pathogenesis to the promotion of plant development (Fahad et al., 2015; Vacheron et al., 2013).

In nature, plant roots undergo various types of interactions with microorganisms. These interactions are usually regulated by various physiochemical and biolo- gical conditions, and become the key element responsible for plant growth and propagation (Dharni et al., 2014). IAA is considered to be the main biologically active plant hormone of the auxin class and is a product of L-tryptophan (Trp) metabolism. IAA stimulates cell elongation by modifying certain conditions, e.g. increase in cell osmotic contents, increase in water permeability into the cell, decrease in wall pressure, increase in cell wall synthesis and by inducing specific RNA and protein biosynthesis. It promotes antioxidant activity, inhibits or delays abscission of leaves, induces flowering and fruiting (Zhao, 2010). IAA is a metabolite derived from Trp by many Trp-dependent and Trp-independent pathways in plants and bacteria. In the Trp-dependent pathway,

\footnotetext{
* Corresponding author: School of Bioengineering and Biosciences, Lovely Professional University, Jalandhar-Delhi G.T. Road, National Highway 1, Phagwara, Punjab 144411, India; e-mail: arunarnwal@gmail.com
} 
Trp is converted to indole-3-acetamide (IAM) by Trp-2monooxigenase, and IAM is metabolized to IAA by IAMhydrolase (Matsukawa et al., 2007). Several microorganisms i.e. Alcaligenes, Arthobacter, Azospirillum, Azotobacter, Bacillus, Burkholderia, Enterobacter, Klebsiella, Pseudomonas, and Serratia support L-Trp metabolism naturally under the impact of plant root exudates including carbohydrates, organic acids, amino acids, mucilages, phenolic compounds, fatty acids, sterols, and vitamins (Nehra et al., 2016; Passari et al., 2016).

A substantial volume of literature that summarizes the promising applications of plant-linked microorganisms such as plant growth stimulating agents and soilplant fitness controllers is available (Jha et al., 2012; Li et al., 2013; Melo et al., 2016). Plant growth-promoting bacteria (PGPB) are usually linked with various plant species and are found where particular plant species grow, and therefore occupy different environments. One of the most extensively examined classes of PGPB is plant growth-promoting rhizobacteria that colonize the rhizosphere, the rhizo-plane (root surface), or the roots itself, i.e. within radicular tissues. Regardless of the diverse environmental availability, free-living rhizobacteria and symbiotic bacteria utilize several identical mechanisms in order to enhance plant development and management of phytopathogens (Navarro-Torre et al., 2016).

Rhizosphere competence as a biocontrol agent comprises effective root colonization combined with the ability to survive and proliferate along growing plant roots over a considerable time period in the presence of the endophytic microflora. The aim of the present study was to analyze the effect of L-Trp and maize root exudates on the production of IAA by two bacterial isolates.

\section{Material and methods}

\section{Microorganisms and culture conditions}

Strains for the present study were collected from oilcontaminated soil near fuel filling stations $\left(30^{\circ} 94^{\prime} \mathrm{N}\right.$, $76^{\circ} 78^{\prime} \mathrm{E}$ ) in Baddi, Himachal Pradesh, India. The isolates were purified on Bushnell Haas agar supplemented with $0.1 \%$ crude oil procured from the Indian Institute of Petroleum, Dehradun $\left(30^{\circ} 26^{\prime} \mathrm{N}, 78^{\circ} 07^{\prime} \mathrm{E}\right)$, followed by a serial dilution technique at $32 \pm 1^{\circ} \mathrm{C}$ (Islam et al., 2013). The composition of Bushnell Haas agar was $0.2 \mathrm{~g} \cdot 1^{-1}$ magnesium sulfate, $0.02 \mathrm{~g} \cdot \mathrm{l}^{-1}$ calcium chloride, $1 \mathrm{~g} \cdot 1^{-1}$ monopotassium phosphate, $1 \mathrm{~g} \cdot 1^{-1}$ dipotassium phosphate, $1 \mathrm{~g} \cdot 1^{-1}$ ammonium nitrate, $0.05 \mathrm{~g} \cdot 1^{-1}$ ferric chloride, and $20 \mathrm{~g} \cdot 1^{-1}$ agar. The final $\mathrm{pH}$ of the medium was adjusted to $7.0 \pm 0.2$ before autoclaving. Biosurfactant production and biochemical characterization of isolates were done in a previous study (Karnwal, 2017) using the Hemolysis assay, Bacterial Adherence to Hydrocarbons assay and Cetyltrimethylammonium bromide assay.

\section{6s rDNA sequencing}

16S rDNA sequencing and phylogenetic analysis were done for both isolates. The universal 16S rDNA bacterial primers 534r (5'-ATTACCGCGGCTGCTGG-3') and U1517R (5' -ACGGCTACCTTGTTACGACTT- $\left.3^{\prime}\right)$ were used for 16S rDNA amplification using polymerase chain reaction (PCR) conditions as described previously (Srinivasan et al., 2015). ProbeBase online software and BLAST (Genbank database) were used to verify the specificity of the primers. For multiple sequence alignment analysis of sequences, MUSCLE (MUltiple Sequence Comparison by Log-Expectation) alignment algorithm was applied (Karnwal, 2017). PhyML software was used for the phylogenetic analysis of multiple sequence alignment sequences (Dereeper et al., 2008).

\section{Indoles and IAA production}

Bacterial isolates were tested for indole production using the method described by Patten and Glick (1996). Dworkin and Foster salt medium $\left(\mathrm{KH}_{2} \mathrm{PO}_{4} 4 \mathrm{~g} \cdot \mathrm{l}^{-1}\right.$, $\left(\mathrm{NH}_{4}\right)_{2} \mathrm{SO}_{4} 2 \mathrm{~g} \cdot 1^{-1}, \mathrm{Na}_{2} \mathrm{HPO}_{4} 6 \mathrm{~g} \cdot 1^{-1}, \mathrm{MgSO}_{4} \cdot 7 \mathrm{H}_{2} \mathrm{O}$ $0.2 \mathrm{~g} \cdot 1^{-1}, \mathrm{FeSO}_{4} \cdot 7 \mathrm{H}_{2} \mathrm{O} 1 \mathrm{mg} \cdot 1^{-1}, \mathrm{H}_{3} \mathrm{BO}_{3} 10 \mu \mathrm{g} \cdot 1^{-1}$, $\mathrm{MnSO}_{4} \cdot \mathrm{ZnSO}_{4} 10 \mu \mathrm{g} \cdot \mathrm{l}^{-1}, \mathrm{CuSO}_{4} 50 \mu \mathrm{g} \cdot \mathrm{l}^{-1}$, and $\mathrm{MoO}_{3}$ $10 \mu \mathrm{g} \cdot \mathrm{l}^{-1}$ ) supplemented with various concentrations of L-Trp $\left(0,50,100,200\right.$, and $\left.500 \mu \mathrm{g} \cdot \mathrm{ml}^{-1}\right)$ in culture tubes (Karnwal, 2009) were used for propagation of isolates. All experiments were performed in triplicate. Culture tubes were placed in the incubator shaker at $28 \pm 2^{\circ} \mathrm{C}$ for $48 \mathrm{hrs}$ and shaken at $80 \mathrm{rpm}$. Following incubation, the bacteria inoculated broth was centrifuged at $4000 \mathrm{rpm}$ for $20 \mathrm{~min}$ at $4^{\circ} \mathrm{C}$ to separate the bacteria from the broth. One $\mathrm{ml}$ of the supernatant was mixed with $4 \mathrm{ml}$ of Salkwaski's reagent (2\% ferric chloride $[0.5 \mathrm{M}]$ in $35 \%$ perchloric acid) and incubated at $28 \pm 2^{\circ} \mathrm{C}$ for $15 \mathrm{~min}$ to analyze the indole production by bacterial isolates. The pink coloration was a positive indication of indole production. The absorbance of samples was recorded at $535 \mathrm{~nm}$ using UV-VIS Spectrophotometer 
2201 (Systronics, India). A standard curve of indole (Himedia. Laboratories Pvt. Ltd., Mumbai) was used for the calculation of the final indole concentration in the samples (Karnwal, 2009).

The immunoenzymatic ELISA test was employed for the estimation of the IAA concentration, produced by K. rosea VB1 and A. luteolus VB2 as described by Karnwal (2009). Methylation of the supernatant was performed by adding 4 drops of $2 \mathrm{M}$ trimethylsilyldiazomethane in diethyl ether (Sigma-Aldrich). Three ml of methylated supernatant was vortexed for $1 \mathrm{~min}$ and placed in a fume hood to enable evaporation of excess ether from the samples for assay. These methylated supernatants supplemented with $0,100,200$, and $500 \mu \mathrm{g} \cdot \mathrm{ml}^{-1}$ of L-Trp were used for the assay procedure.

The color developed upon the adjunction of antibodies with the substrate is inversely related to the quantity of the phytohormone within the tested sample. The depth of the color was examined by spectrophotometric analysis at $405 \mathrm{~nm}$ on an ELISA plate reader using ELISA kits (Phytodetek, Agdia, USA). Stock solutions $\left(10 \mu \mathrm{mol} \cdot \mathrm{ml}^{-1}\right)$ of the IAA (Himedia. Laboratories Pvt. Ltd., Mumbai) were prepared in absolute methanol. Standard concentrations of $78-2500 \mathrm{pmol} \cdot \mathrm{ml}^{-1}$ (IAA) were used. One hundred $\mu \mathrm{l}$ of the standard or the sample were used for each assay (Karnwal, 2009).

\section{Growth pouch study and determination of IAA production levels}

A growth pouch study was carried out with maize seeds (Zea mays L. "Kissan") collected from the regional market of Dehradun $\left(30^{\circ} 19^{\prime} \mathrm{N}, 78^{\circ} 04^{\prime} \mathrm{E}\right)$, Uttarakhand, India. For the in vitro growth pouch study, seeds were surface disinfected by soaking in $95 \%$ ethanol (v/v) for 10 to $20 \mathrm{~s}$, followed by immersion in $20 \%$ bleaching solution (v/v) for $10 \mathrm{~min}$. The seeds were rinsed with sterile distilled water 8 times to eliminate the surplus bleach. A bacterial suspension grown in a Tryptic soy broth medium (pancreatic digest of casein $17 \mathrm{~g} \cdot 1^{-1}$, papaic digest of soybean meal $3 \mathrm{~g} \cdot 1^{-1}, \mathrm{NaCl} 5 \mathrm{~g} \cdot 1^{-1}$, $\mathrm{C}_{6} \mathrm{H}_{12} \mathrm{O}_{6} 2.5 \mathrm{~g} \cdot 1^{-1}, \mathrm{~K}_{2} \mathrm{HPO}_{4} 2.5 \mathrm{~g} \cdot 1^{-1}, \mathrm{pH} 7.3 \pm 0.2$ ) was used for inoculation and soaking experiments. After disinfection, the maize seeds were air-dried and soaked for 10-15 min in $10 \mathrm{ml}$ of the bacterial suspension (tested strains) having $10^{8}$ cells density. For the growth pouch experiment, bacteria-treated seeds were aseptically inoculated in growth pouches (three seeds per pouch and three pouches for each bacterial strain) filled with $30 \mathrm{ml}$ of half-strength $\mathrm{N}$-free Hoagland broth (Hoagland and Arnon, 1938). Seeds treated with $0.1 \mathrm{M} \mathrm{MgSO}_{4}$ were considered as controls.

The growth pouches with bacteria-treated seeds were cultured inside the plant growth chamber along with regular shaking at $100 \mathrm{rpm}$ for maintaining the aerobic state for bacterial growth. Ten $\mathrm{ml}$ cell-free supernatants from growth pouches were collected after centrifugation at $4000 \mathrm{rpm}$ for $20 \mathrm{~min}$ at $4{ }^{\circ} \mathrm{C}$ and filtration using $0.22 \mu \mathrm{m}$ membrane filters. The filtrate was used to detect and quantify the concentration of IAA production by VB1 and VB2 bacterial isolates using ELISA. Aliquots of filtrates $(3 \mathrm{ml})$ were methylated by adding 4 to 5 drops of $2.0 \mathrm{M}$ trimethylsilyldiazomethane in diethyl ether. Next, samples were vortexed at a high speed for $1 \mathrm{~min}$ and placed in a fume hood for excess ether to evaporate. IAA was assayed using ELISA kits (Phytodetek, Agdia, USA). Stock solutions $\left(10 \mu \mathrm{mol} \cdot \mathrm{ml}^{-1}\right)$ of the IAA (Himedia Laboratories Pvt. Ltd, Mumbai) were prepared in absolute methanol. Standard concentrations of 78$2500 \mathrm{pmol} \cdot \mathrm{ml}^{-1}(\mathrm{IAA})$ were used. One hundred $\mu \mathrm{l}$ of the standard or the sample were used for each assay.

\section{Statistical analysis}

Significant differences between treatments were determined using variance analysis with a $P$ value of $\leq 0.05$ and pair-wise comparisons were conducted using Tukey's Studentized Range (HSD, honestly significant difference) test using Statistical Analysis System software.

\section{Results and discussions}

Soil is one of the best media for the growth of all microscopic life forms, i.e. algae, fungi, actinomycetes, bacteria, and protozoa. Bacteria are the most common microscopic life forms found in all soil types with cell density varying from $10^{8}$ to $10^{9}$ cells per $\mathrm{g}$ of soil (Huang et al., 2013). However, within ecologically stressed soil, the quantity of culturable bacteria might be as little as $10^{4}$ cells per $g$ of soil. Both the quantity and the variety of bacterial strains that are present in diverse soils are affected by soil factors, i.e. temperature, humidity, salt concentration, and various other chemical substances, as well as with the quantity and types of vegetation present in those soils (Glick, 2012). 


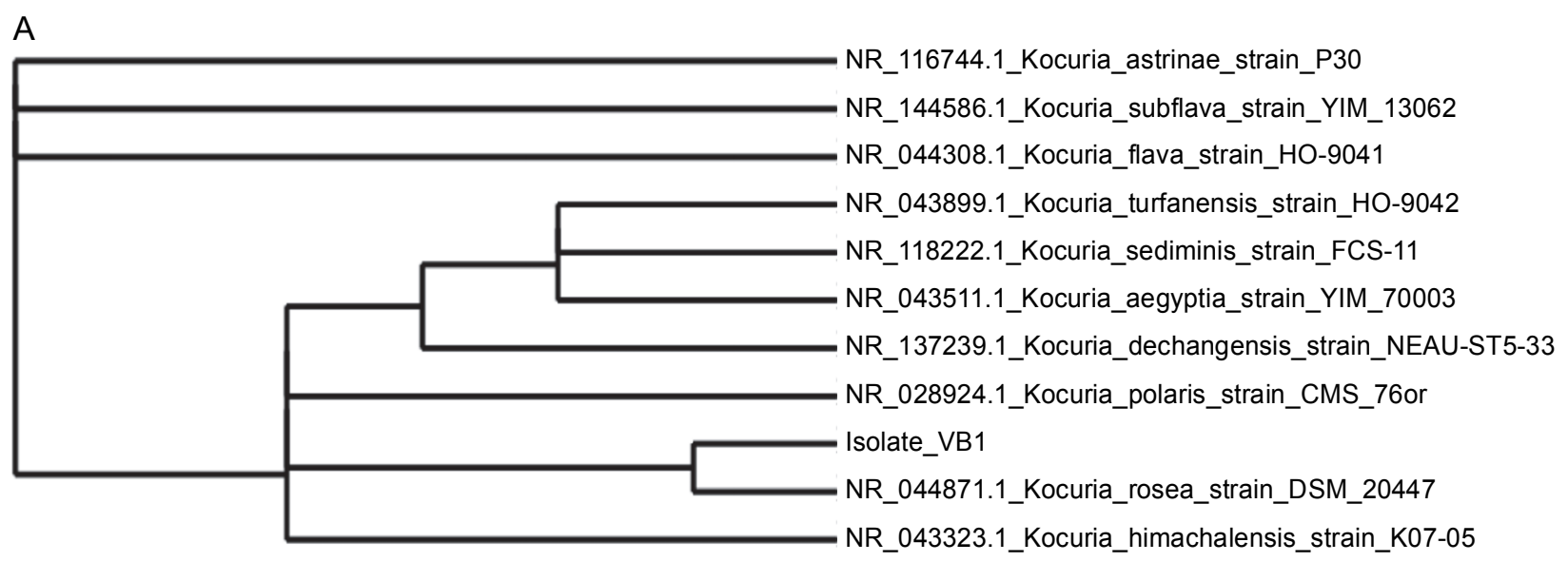

B

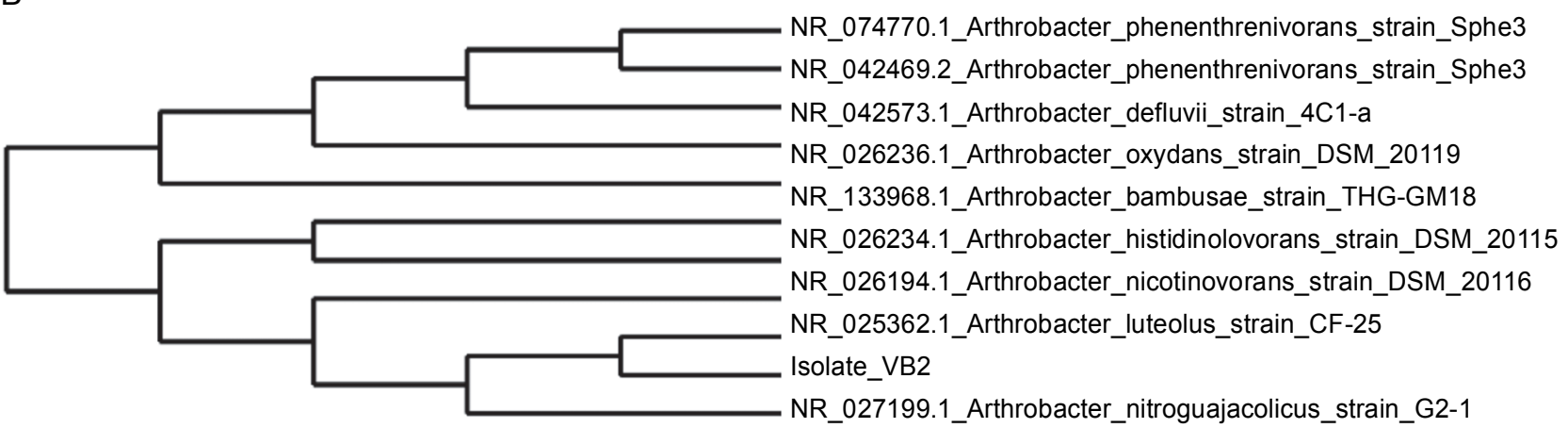

Fig. 1. A phylogenetic tree of bacterial isolates based on $16 \mathrm{~S}$ rDNA sequence similarity using TreeDyn, Tree Rendering software based on MUSCLE alignment data, A) BLAST similarity search results and phylogenetic tree for isolate VB1, B) A phylogenetic tree for isolate VB2

The aim of present study was to analyze the indole and IAA production potential of VB1 and VB2 inoculants with or without L-Trp and maize root exudates. In a previous study (Karnwal, 2017), it was confirmed that both isolates are able to produce biosurfactants that may be used as an indirect mechanism for biocontrol of phytopathogens (Sathi Reddy et al., 2016). Both bacterial isolates VB1 and VB2 were identified on the basis of the Gram reaction, biochemical activities, and sugar fermentation from a previous study conducted by Karnwal (2017). BLAST (Basic Local Alignment Search Tool) analysis of the $16 \mathrm{~S}$ rDNA gene encoding sequence of VB1 and VB2 isolates showed maximum sequence similarity with $K$. rosea strain DSM 20447 (99\% identical) and A. luteolus strain CF-25 (95\%), respectively, as shown in the phylogenetic tree analysis done using MUSCLE alignment algorithm and TreeDyn phylogenetic tree building software (Fig. 1).

IAA is a phytohormone and is generally considered to be the most important native auxin. It has been reported that $80 \%$ of the bacteria isolated from the soil can produce IAA (Patten and Glick, 1996). Most of the earlier studies showed that IAA-producing organisms are Gramnegative (Lindow et al., 1998; Datta and Basu, 2000). Only a few Gram-positive bacterial strains belonging to Kocuria (Goswami et al., 2014; Hansda et al., 2017) and Arthrobacter (Ozdal et al., 2017; Etesami et al., 2015) are known to produce IAA. A previous study showed that $K$. rosea VB1 and $A$. luteolus VB2 used in the present study are Gram-positive (Karnwal, 2017).

L-Trp is considered to be a precursor to IAA production (Ahmad et al., 2005; Santi et al., 2007; Desale et al., 2014). IAA biosynthesis in various Arthrobacter and Kocuria species is stimulated by the application of exogenous Trp (Katznelson and Sirois, 1961; Forni et al., 1992; Yadav et al., 2015). Similarly, in the current study, $K$. rosea VB1 and A. luteolus VB2 were screened for their potential to produce and secrete indole and IAA (Tables 1-3). Detection of indole using the Van Urk Salkowski reagent is a way for the qualitative and quanti- 
Table 1. Comparison of indole production $\left(\mu \mathrm{g} \cdot \mathrm{ml}^{-1}\right)$ by the bacterial isolates in media supplemented with various tryptophan (Trp) concentrations

\begin{tabular}{c|c|c}
\hline $\begin{array}{c}\text { L-Trp concentration } \\
{\left[\mu \mathrm{g} \cdot \mathrm{ml}^{-1}\right]}\end{array}$ & \multicolumn{2}{|c}{ Indole concentration $\left[\mu \mathrm{g} \cdot \mathrm{ml}^{-1}\right]$} \\
\cline { 2 - 3 } & K. rosea VB1 & A. luteolus VB2 \\
\hline 0 & $0.33 \pm 0.09^{\mathrm{a}}$ & $0.63 \pm 0.23^{\mathrm{f}}$ \\
\hline 50 & $0.47 \pm 0.09^{\mathrm{ab}}$ & $1.47 \pm 0.27^{\mathrm{g}}$ \\
\hline 100 & $4.57 \pm 0.73^{\mathrm{c}}$ & $3.57 \pm 0.20^{\mathrm{h}}$ \\
\hline 200 & $11.43 \pm 0.85^{\mathrm{d}}$ & $5.50 \pm 0.25^{\mathrm{i}}$ \\
\hline 500 & $18.17 \pm 0.66^{\mathrm{e}}$ & $9.23 \pm 0.15^{\mathrm{j}}$ \\
\hline
\end{tabular}

Values represent the mean of three replicates \pm standard error of the mean $(n=15)$; letters above standard error indicate values that are significantly different $(P<0.05)$ between treatments

Table 2. Production of indole acetic acid (IAA) $\left(\mathrm{ng} \cdot \mathrm{ml}^{-1}\right)$ by VB1 and VB2 isolates in media supplemented with various concentrations of L-Trp

\begin{tabular}{c|c|c}
\hline $\begin{array}{c}\text { L-Trp concentration } \\
{\left[\mu \mathrm{g} \cdot \mathrm{ml}^{-1}\right]}\end{array}$ & \multicolumn{2}{|c}{ IAA concentration $\left[\mathrm{ng} \cdot \mathrm{ml}^{-1}\right]$} \\
\cline { 2 - 3 } & K. rosea VB1 & A. luteolus $\mathrm{VB} 2$ \\
\hline 0 & $4.2 \pm 1.11^{\mathrm{a}}$ & $8.33 \pm 1.64^{\mathrm{e}}$ \\
\hline 100 & $24.8 \pm 1.74^{\mathrm{b}}$ & $41.5 \pm 1.76^{\mathrm{f}}$ \\
\hline 200 & $78.4 \pm 2.09^{\mathrm{c}}$ & $70.33 \pm 1.20^{\mathrm{g}}$ \\
\hline 500 & $123.7 \pm 2.72^{\mathrm{d}}$ & $85.06 \pm 1.55^{\mathrm{h}}$ \\
\hline
\end{tabular}

Values represent the mean of three replicates \pm standard error of the mean $(n=12)$; letters above standard error indicate values that are significantly different $(P<0.05)$ between treatments

Table 3. IAA concentration $\left(\mathrm{ng} \cdot \mathrm{ml}^{-1}\right)$ in growth pouches inoculated with or without indigenous isolates

\begin{tabular}{l|c}
\hline \multicolumn{1}{c|}{ Treatments } & $\begin{array}{c}\text { IAA concentration } \\
{\left[\mathrm{ng} \cdot \mathrm{ml}^{-1}\right]}\end{array}$ \\
\hline Non-inoculated & $4.73 \pm 0.93^{\mathrm{a}}$ \\
\hline K. rosea VB1 & $66.37 \pm 1.21^{\mathrm{b}}$ \\
\hline A. luteolus VB2 & $54.27 \pm 1.75^{\mathrm{c}}$ \\
\hline
\end{tabular}

Values represent the mean of three replicates \pm standard error of the mean $(n=9)$; letters above standard error indicate values that are significantly different $(P<0.05)$ between treatments.

tative determination of the presence of the hormone in the supernatant of bacterial cultures or liquid formulations of biological inoculants. The data previously published indicated that the amount of indole produced by the bacteria was within the detection limits of the Salkowski reagent (Ehmann, 1977). We also detected a significant increase in indole production after the addition of Trp to the Dworkin and Foster salt medium, indica- ting that indole biosynthesis in VB1 and VB2 is induced by Trp. In the absence of L-Trp, the VB2 isolate released considerable levels of indole $\left(0.63 \mu \mathrm{g} \cdot \mathrm{ml}^{-1}\right)$ in comparison with VB1 $\left(0.33 \mu \mathrm{g} \cdot \mathrm{ml}^{-1}\right)$. In the presence of $50 \mu \mathrm{g} \cdot \mathrm{ml}^{-1}$ of L-Trp, VB2 produced a significantly higher $\left(1.47 \mu \mathrm{g} \cdot \mathrm{ml}^{-1}\right)$ concentration of indole than VB1 $\left(0.47 \mu \mathrm{g} \cdot \mathrm{ml}^{-1}\right)$. When $200 \mu \mathrm{g} \cdot \mathrm{ml}^{-1}$ of L-Trp was added to the medium, VB1 and VB2 inoculants produced $11.43 \mu \mathrm{g} \cdot \mathrm{ml}^{-1}$ and $5.5 \mu \mathrm{g} \cdot \mathrm{ml}^{-1}$ indole respectively, higher than when L-Trp was supplemented at $50 \mu \mathrm{g} \cdot \mathrm{ml}^{-1}$ (Table 1). A significant increase in indole production was observed in a medium supplemented with $500 \mu \mathrm{g} \cdot \mathrm{ml}^{-1} \mathrm{~L}$-Trp i.e. $18.17 \mu \mathrm{g} \cdot \mathrm{ml}^{-1}$ and $9.23 \mu \mathrm{g} \cdot \mathrm{ml}^{-1}$, respectively for VB1 and VB2 isolates (Table 1).

IAA production by bacteria can vary between different species and strains, and it is also influenced by culture condition, growth stage, and substrate availability (Mutluru and Konada, 2007). Moreover, isolates from the rhizosphere are more efficient auxin producers than isolates from the bulk soil (Sarwar and Kremer, 1992). L-Trp also significantly affected the production of IAA by both isolates (Table 2). ELISA kit assay (Phytodetek, Agdia, USA) results confirmed that VB1 has higher IAA production ability than VB2. At zero L-Trp concentration, VB1 and VB2 produced 4.2 and $8.33 \mathrm{ng} \cdot \mathrm{ml}^{-1}$ IAA, respectively (Table 2). The outcomes of the current research have shown a substantial increase in the biosynthesis of IAA at 100,200 , and $500 \mu \mathrm{g} \cdot \mathrm{ml}^{-1}$ of L-Trp concentration by VB1 as shown in Table 2 . The maximum IAA biosynthesis $\left(123.7 \mathrm{ng} \cdot \mathrm{ml}^{-1}\right)$ by VB1 isolate was recorded with $500 \mu \mathrm{g} \cdot \mathrm{ml}^{-1}$ of L-Trp concentration, whereas at $200 \mu \mathrm{g} \cdot \mathrm{ml}^{-1}$ of L-Trp concentration VB1 secreted $78.4 \mathrm{ng} \cdot \mathrm{ml}^{-1}$ IAA. In the same manner, an increase in IAA synthesis by VB2 has been detected in the presence of L-Trp $\left(100,200\right.$, and $\left.500 \mu \mathrm{g} \cdot \mathrm{ml}^{-1}\right)$, i.e. 41.5 , 70.33 , and $85.06 \mathrm{ng} \cdot \mathrm{ml}^{-1}$, respectively. Our results are in agreement with the work of Khalid et al. (2004), who studied the effect of L-Trp concentration on the production of IAA and observed that L-Trp-derived auxin biosynthesis had been enhanced several folds. The authors (Khalid et al. 2004) showed that rhizobacteria produced variable amounts of auxins in vitro. Moreover, the supplementation of the culture media with L-Trp stimulated further auxin biosynthesis. Tien et al., (1979) showed that Azospirillum is able to produce auxins when exposed to Trp. Karnwal (2009) tested fluorescent $P$ seudomonas isolates for their ability to produce IAA in a pure 
culture in the absence and in the presence of L-Trp and found that for both strains, indole production was enhanced with increases in the Trp concentration.

A growth pouch study confirmed the positive effect of maize root exudates on IAA biosynthesis by both isolates in the range 54.26 to $66.38 \mathrm{ng} \cdot \mathrm{ml}^{-1} \mathrm{IAA}$, which is a significant increase compared to that of the control (Table 3). These results support the hypothesis that plant rhizome secretes various chemicals in the form of root exudates that support the colonization and development of various free-living microscopic life forms (Benidire et al., 2016; Passari et al., 2016; Zahid et al., 2015). The property of synthesizing IAA is considered to be an effective tool for screening beneficial microorganisms, suggesting that IAA-producing bacteria have a profound effect on plant growth (Wahyudi et al., 2011). Inoculation with IAA-producing bacteria induces proliferation of lateral roots and root hairs. Fatima et al., (2009) also showed that the germination rate as well as the root and shoot growth of the plant were increased by IAA and plant growth-promoting rhizobacteria.

\section{Conclusions}

The bacterial strains VB1 and VB2 showed potential as PGPB due to their phenotypic characteristics as well as their capacity for IAA biosynthesis. This study has provided an insight into the effect of free-living bacterial inoculants on the growth of inoculated maize seeds. IAA and indole production are considered to be important plant growth-promoting traits and the inoculation of maize seed with VB2 and VB1 showed a significantly higher level of IAA production in comparison to noninoculated seeds. From this study, it is also clear that free-living bacteria have the ability to produce a significant amount of IAA in a Trp-supplemented medium. It has been concluded that the presence of growth-promoting bacteria is responsible for the beneficial effects on crop growth and yield.

\section{References}

Ahmad F., Ahmad I., Khan M.S. (2005) Indole acetic acid production by the indigenous isolates of Azotobacter and fluorescent Pseudomonas in the presence and absence of tryptophan. Turk. J. Biol. 29: 29-34.

Asari S., Tarkowska D., Rolcik J., Novak O., Palmero D.V., Bejai S., Meijer J. (2016) Analysis of plant growth-pro- moting properties of bacillus amyloliquefaciens ucmb5113 using arabidopsis thaliana as host plant. Planta 245(1): 15-30.

Benidire L., Pereira S.I., Castro P.M., Boularbah A. (2016) Assessment of plant growth promoting bacterial populations in the rhizosphere of metallophytes from the kettara mine, marrakech. Environ. Sci. Pollut. Res. Int. 23(21): 21751-21765.

Dereeper A., Guignon V., Blanc G., Audic S., Buffet S., Chevenet F., Dufayard J.F., Guindon S., Lefort V., Lescot M. et al. (2008) Phylogeny. Fr: Robust phylogenetic analysis for the non-specialist. Nucl. Acids Res. 36(suppl. 2): W465-W469.

Desale P., Patel B., Singh S., Malhotra A., Nawani N. (2014) Plant growth promoting properties of Halobacillus sp. and Halomonas sp. in presence of salinity and heavy metals. J. Basic. Microbiol. 54(8): 781-791.

Dharni S., Srivastava A.K., Samad A., Patra D.D. (2014) Impact of plant growth promoting Pseudomonas monteilii psf84 and Pseudomonas plecoglossicida psf610 on metal uptake and production of secondary metabolite (monoterpenes) by rose-scented geranium (Pelargonium graveolens $\mathrm{cv}$. Bourbon) grown on tannery sludge. Chemosphere 117: 433-439.

Etesami H., Alikhani H.A., Hosseini H.M. (2015) Indole-3-acetic acid (IAA) production trait, a useful screening to select endophytic and rhizosphere competent bacteria for rice growth promoting agents. MethodsX. 2: 72-78.

Fahad S., Hussain S., Bano A., Saud S., Hassan S., Shan D., Khan F.A., Khan F., Chen Y., Wu C. et al. (2015) Potential role of phytohormones and plant growth-promoting rhizobacteria in abiotic stresses: Consequences for changing environment. Environ. Sci. Pollut. Res. Int. 22(7): 4907-4921.

Forni C., Riov J., Grilli M.G., Tel-Or E. (1992) Indole-3-acetic acid (IAA) production by Arthrobacter species isolated from Azolla. Microbiol. 138: 377-381.

Glick B.R. (2012) Plant growth-promoting bacteria: Mechanisms and applications. Scientifica 2012: 963401.

Goswami D., Pithwa S., Dhandhukia P., Thakker J.N. (2014) Delineating Kocuria turfanensis 2M4 as a credible PGPR: A novel IAA producing bacteria isolated from saline desert. J. Plant. Interact. 9(1): 566-576.

Hansda A., Kumar V., Anshumali (2017) Cu-resistant Kocuria sp. CRB15: a potential PGPR isolated from the dry tailing of Rakha copper mine. 3 Biotech. 7(2): 132.

Hoagland D.R., Arnon D.I. (1938) The water culture method for growing plants without soil. California Agr. Exp. Sta. Cir. Vol. 337.

Huang G.H., Tian H.H., Liu H.Y., Fan X.W., Liang Y., Li Y.Z. (2013) Characterization of plant-growth-promoting effects and concurrent promotion of heavy metal accumulation in the tissues of the plants grown in the polluted soil by burkholderia strain ld-11. Int. J. Phytoremediation 15(10): 991-1009.

Islam T.H., Ghosh B., Datta S. (2013) Isolation and identification of petroleum degrading bacteria from soil and water 
and assessment of their potentiality in bioremediation. IOSR J. Environ. Sci. Toxicol. Food. Technol. 5(2): 55-58.

Jha C.K., Patel B., Saraf M. (2012) Stimulation of the growth of Jatropha curcas by the plant growth promoting bacterium Enterobacter cancerogenus msa2. World. J. Microbiol. Biotechnol. 28(3): 891-899.

Karnwal A. (2009) Production of indole acetic acid by fluorescent pseudomonas in the presence of L-tryptophan and rice root exudates. J. Plant. Path. 19(1): 61-63.

Karnwal A. (2017) Biosurfactant production by Kocuria rosea and Arthrobacter luteolus using sugar cane waste as substrate. II Ponte. 73: 20-29.

Katznelson H., Sirois J.C. (1961) Auxin production by species of Arthrobacter. Nature 191: 1323-1324.

Khalid A., Arshad M., Zahir Z.A. (2004) Screening plant growth promoting rhizobacteria for improving growth and yield of wheat. J. Appl. Microbiol. 96: 473-480.

Li J., McConkey B.J., Cheng Z., Guo S., Glick B.R. (2013) Identification of plant growth-promoting bacteria-responsive proteins in cucumber roots under hypoxic stress using a proteomic approach. J. Proteomics 84: 119-131.

Matsukawa E., Nakagawa Y., Iimura Y., Hayakawa M. (2007) Stimulatory effect of indole-3-acetic acid on aerial mycelium formation and antibiotic production in Streptomyces spp. Actinomycetologica 21: 32-39.

Melo J., Carolino M., Carvalho L., Correia P., Tenreiro R., Chaves S., Meleiro A.I., de Souza S.B., Dias T., Cruz C. et al. (2016) Crop management as a driving force of plant growth promoting rhizobacteria physiology. Springerplus 5(1): 1574.

Navarro-Torre S., Mateos-Naranjo E., Caviedes M.A., Pajuelo E., Rodriguez-Llorente I.D. (2016) Isolation of plantgrowth-promoting and metal-resistant cultivable bacteria from Arthrocnemum macrostachyum in the odiel marshes with potential use in phytoremediation. Mar. Pollut. Bull. 110: 133-142.

Nehra V., Saharan B.S., Choudhary M. (2016) Evaluation of Brevibacillus brevis as a potential plant growth promoting rhizobacteria for cotton (Gossypium hirsutum) crop. Springerplus 5(1): 948.
Ozdal M., Ozdal O.G., Sezen A., Algur O.F., Kurbanoglu E.B. (2017) Continuous production of indole-3-acetic acid by immobilized cells of Arthrobacter agilis. 3 Biotech. 7(1): 23.

Passari A.K., Mishra V.K., Leo V.V., Gupta V.K., Singh B.P. (2016) Phytohormone production endowed with antagonistic potential and plant growth promoting abilities of culturable endophytic bacteria isolated from Clerodendrum colebrookianum walp. Microbiol. Res. 193: 57-73.

Patten C., Glick B.R. (1996) Bacterial biosynthesis of indole3-acetic acid. Can. J. Microbiol. 42: 207-220.

Santi M., Keshab C., Dey S., Pati B.R. (2007) Optimization of cultural and nutritional conditions for indole acetic acid production by a Rhizobium sp. isolated from root nodules of Vigna mungo (L.) Hepper. Res. J. Microbiol. 2: 239-246.

Sathi Reddy K., Yahya Khan M., Archana K., Gopal Reddy M., Hameeda B. (2016) Utilization of mango kernel oil for the rhamnolipid production by Pseudomonas aeruginosa dr1 towards its application as biocontrol agent. Bioresour. Technol. 221: 291-299.

Srinivasan R., Karaoz U., Volegova M., MacKichan J., KatoMaeda M. (2015) Use of 16s rrna gene for identification of a broad range of clinically relevant bacterial pathogens. PLOS ONE 10(2).

Vacheron J., Desbrosses G., Bouffaud M.L., Touraine B., Moenne-Loccoz Y., Muller D., Legendre L., Wisniewski-Dye F., Prigent-Combaret C. (2013) Plant growth-promoting rhizobacteria and root system functioning. Front. Plant. Sci. 4: 356

Yadav A.N., Sachan S.G., Verma P., Tyagi S.P., Kaushik R., Saxena A.K. (2015) Culturable diversity and functional annotation of psychrotrophic bacteria from cold desert of Leh Ladakh (India). World J. Microbiol. Biotechnol. 31: 95-108.

Zahid M., Abbasi M.K., Hameed S., Rahim N. (2015) Isolation and identification of indigenous plant growth promoting rhizobacteria from Himalayan region of Kashmir and their effect on improving growth and nutrient contents of maize (Zea mays 1.). Front. Microbiol. 6: 207.

Zhao Y. (2010) Auxin biosynthesis and its role in plant development. Annu. Rev. Plant. Biol. 61: 49-64. 